\title{
The 16,000-event 2003-2004 earthquake swarm in Ubaye (French Alps)
}

\author{
Liliane Jenatton, ${ }^{1}$ Robert Guiguet, ${ }^{1}$ François Thouvenot, ${ }^{1}$ and Nicolas Daix ${ }^{1}$ \\ Received 30 November 2006; revised 12 June 2007; accepted 30 July 2007; published 7 November 2007.
}

[1] The Ubaye valley, one of the most active seismic zones in the French Alps, was visited in 2003-2004 by a prolific and protracted earthquake swarm with a maximum magnitude $M_{L}=2.7$. The seismic activity clustered along a 9-km-long, 3- to 8-km-deep rupture zone which trends NW-SE across the valley and dips $80^{\circ} \mathrm{SW}$. Focal mechanisms for the larger shocks show either normal faulting with a SW-NE trending extension direction or NW-SE strike slip with right lateral displacement. The activity initiated in the central part of the rupture zone, diffused to its periphery, and eventually concentrated in its southeastern deeper part. A permanent station situated above the swarm allowed us to monitor the entire phenomenon from its inception to its conclusion. The complete time series includes more than 16,000 events, with shocks down to magnitude $M_{L}=-1.3$. It shows bursts of activity, separated by quiescent periods, with no well-defined subswarms as observed in other similar studies. The Gutenberg-Richter $b$ value significantly varied between 1.0 and 1.5 in the course of the phenomenon.

Citation: Jenatton, L., R. Guiguet, F. Thouvenot, and N. Daix (2007), The 16,000-event 2003-2004 earthquake swarm in Ubaye (French Alps), J. Geophys. Res., 112, B11304, doi:10.1029/2006JB004878.

\section{Introduction}

[2] Midway between Grenoble and Nice (France), from the French-Italian border to the Serre-Ponçon reservoir on the Durance River (Figure 1), the $\sim 60$-km-long Ubaye valley is one of the most active seismic zones in the French Alps [Thouvenot and Fréchet, 2006]. Besides the classical mainshock-aftershock sequences the valley is frequently visited by earthquake swarms. These long series of large and small shocks, with no outstanding principal event, occur there every few months and last a few days to several months.

[3] The temporal evolution of earthquake swarms cannot be described by a simple law such as that proposed by Omori [1894] to fit the occurrence rate of aftershocks. Swarms are common in volcanic regions such as Japan, central Italy, Afar, or oceanic ridges, where they occur before and during eruptions [e.g., Kisslinger, 1975; Noir et al., 1997; Aoki et al., 1999]. They are also observed in zones of Quaternary volcanism such as California, Colorado, French Massif Central, or Vogtland/NW Bohemia (border region between Germany and the Czech republic) [e.g., Bott and Wong, 1995; Hainzl and Fischer, 2002; Fischer and Horálek, 2003; Klinge et al., 2003], where fluid migration in a magmatic environment can be invoked. The dynamic evolution of earthquake swarms in intraplate regions [Špičák, 2000], for instance, those observed in Arkansas, Vosges (France), England, or Scotland [e.g., Chiu

\footnotetext{
${ }^{1}$ Laboratoire de Géophysique Interne et Tectonophysique, Observatoire de Grenoble, CNRS/UJF, Grenoble, France.

Copyright 2007 by the American Geophysical Union. 0148-0227/07/2006JB004878\$09.00
}

et al., 1984; Audin et al., 2002; Assumpção, 1981], remains more mysterious, even if fluid migration is a likely regulating factor.

[4] Ubaye is not a volcanic region. Close to the boundary between Eurasia and the colliding Adriatic microplate, usually likened to the Piedmont seismic arc $40 \mathrm{~km}$ to the east [Thouvenot and Fréchet, 2006], it cannot be considered a typical intraplate region either. However, the exceptional earthquake swarm which occurred there in 2003-2004 is of particular interest because the 16,000-event sequence could be studied in detail from the inception of the phenomenon till its conclusion using the surrounding permanent seismic networks. Because this sequence contains potential data on earthquake genesis and fracture propagation, this article aims at presenting the complete time series, the migration of seismic activity along the main fault direction, and clues to significant variations of the Gutenberg-Richter $b$ value with time.

\section{Tectonics and Seismicity}

[5] The Ubaye valley crosses the Frontal Penninic Thrust, the main boundary between the external (French) Alps and the inner (mainly Italian) Alps (Figure 1). Making use of the basement depression between the Pelvoux and Argentera external crystalline massifs, the Embrunais-Ubaye nappes spilled out to the southwest of the Frontal Penninic Thrust onto the external domain. These nappes, made of the 1- to 2-km-thick Upper Cretaceous schist, limestone, and sandstone series known as Flysch à Helminthoïdes, have been in their present place since the Eocene (30 Ma). Their current mobility is unknown, but the seismicity detected in the underlying crystalline basement shows that normal 


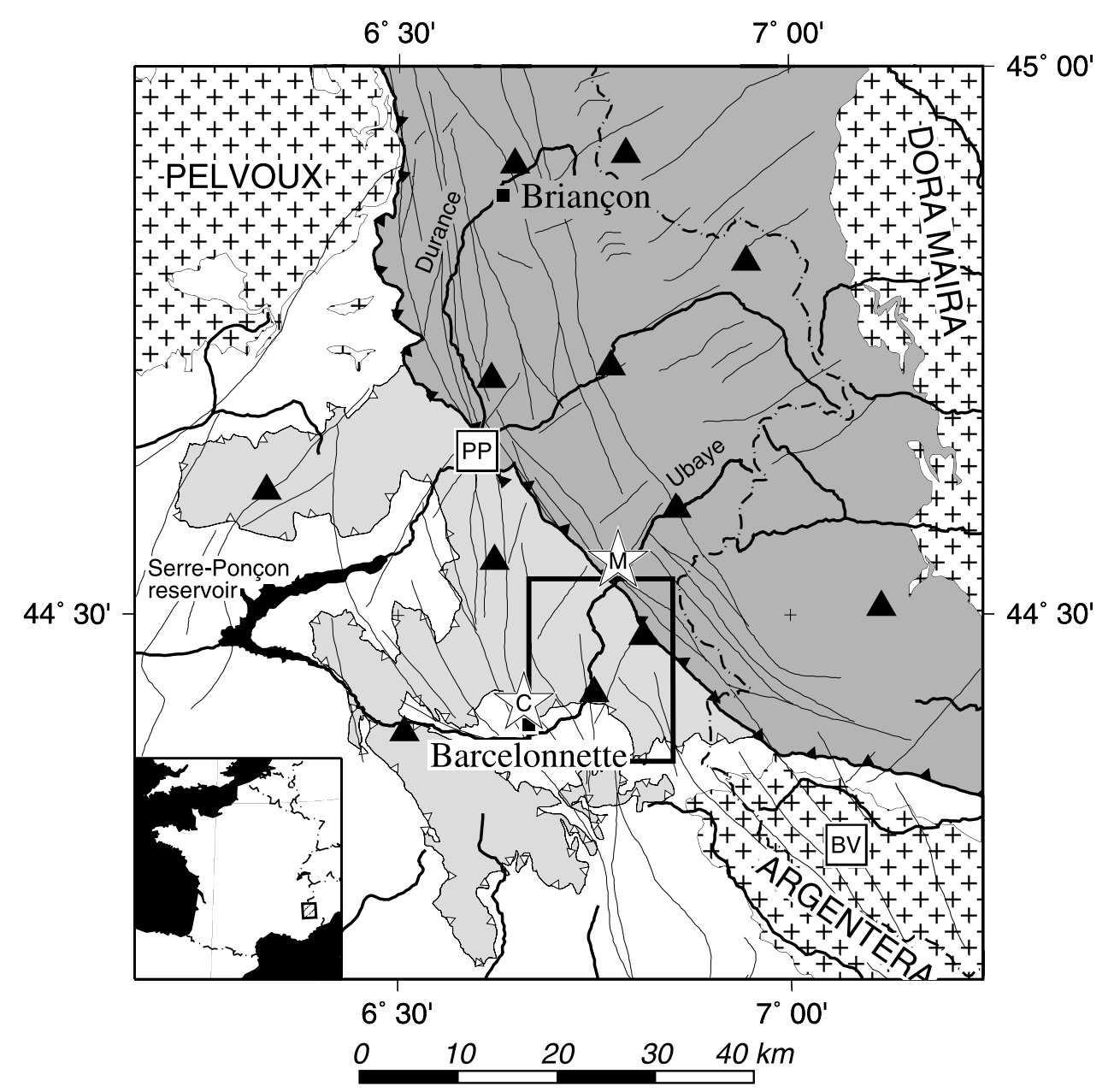

Figure 1. Simplified map of the southwestern Alps with main geological features. The cross patterned area is crystalline massifs (Pelvoux, Argentera, and Dora Maira). The lightly shaded area is EmbrunaisUbaye nappes. The heavily shaded area is Penninic Domain. The thick barbed line is Frontal Penninic Thrust. Faults after Sue [1998]. Stars are macroseismic (M) and computed (C) epicenters of the 1959 M-5.5 damaging earthquake. Triangles are permanent seismic stations (Sismalp, IGG, and LDG). Squares are hot springs: PP, Plan de Phasy; BV, Bagni di Vinádio. The dashed line is the French-Italian border. The boxed area near the center is the study area of Figure 2.

faulting mechanisms with an extension direction perpendicular to the Frontal Penninic Thrust are now the rule in this area [Sue, 1998; Sue et al., 1999].

[6] Our study area $\left(44^{\circ} 22^{\prime}-44^{\circ} 32^{\prime} \mathrm{N}, 6^{\circ} 40^{\prime}-6^{\circ} 51^{\prime} \mathrm{E}\right)$ is located northeast of Barcelonnette, where the upper part of the valley is particularly active. This is where the largest earthquake in the French Alps occurred in the last century (5 April 1959, $M=5.5$ ). It was rated a maximum intensity of VIII on the Medvedev-Sponheuer-Karnik scale at SaintPaul (Figure 2), where several gables and $80 \%$ of chimneys collapsed [Rothé and Dechevoy, 1967]. Although this earthquake was recorded worldwide, seismic stations were few in the western Alps at that time (with the nearest station at Monaco, $106 \mathrm{~km}$ to the south). No foreshock was reported, but many aftershocks were felt, with the Monaco station recording a dozen. The instrumental epicenter computed by Rothé and Dechevoy [1967] is, from the authors' own advice, much less reliable than their macroseismic epicenter (Figure 1) on the northern fringe of the study area. When relocating this event 40 years later, Nicolas et al. [1998] shifted the epicenter $17 \mathrm{~km}$ to the SW of the macroseismic epicenter on the western fringe of the study area. In the present case, site effects cannot explain such a misfit. It leads us to conclude that the epicenter position remains very approximate, and the 1959 earthquake could have also occurred within the study area. The focal solution computed by Fréchet [1978] shows a right lateral strike-slip motion along a $\mathrm{N} 175^{\circ} \mathrm{E}$ striking plane with a small extensional component. Although not well constrained, this is similar to solutions computed for most events of the 2003-2004 swarm (see section 3).

[7] The fact that Ubaye is often visited by earthquake swarms was recognized as early as 1977 , when a pioneering microseismic study with eight portable seismic stations allowed the detailed observation of such a swarm over a 4-week period [Fréchet, 1978; Fréchet and Pavoni, 1979]. That swarm, as for most swarms in the area, occurred NE of Saint-Paul, beneath the Chambeyron massif which marks 


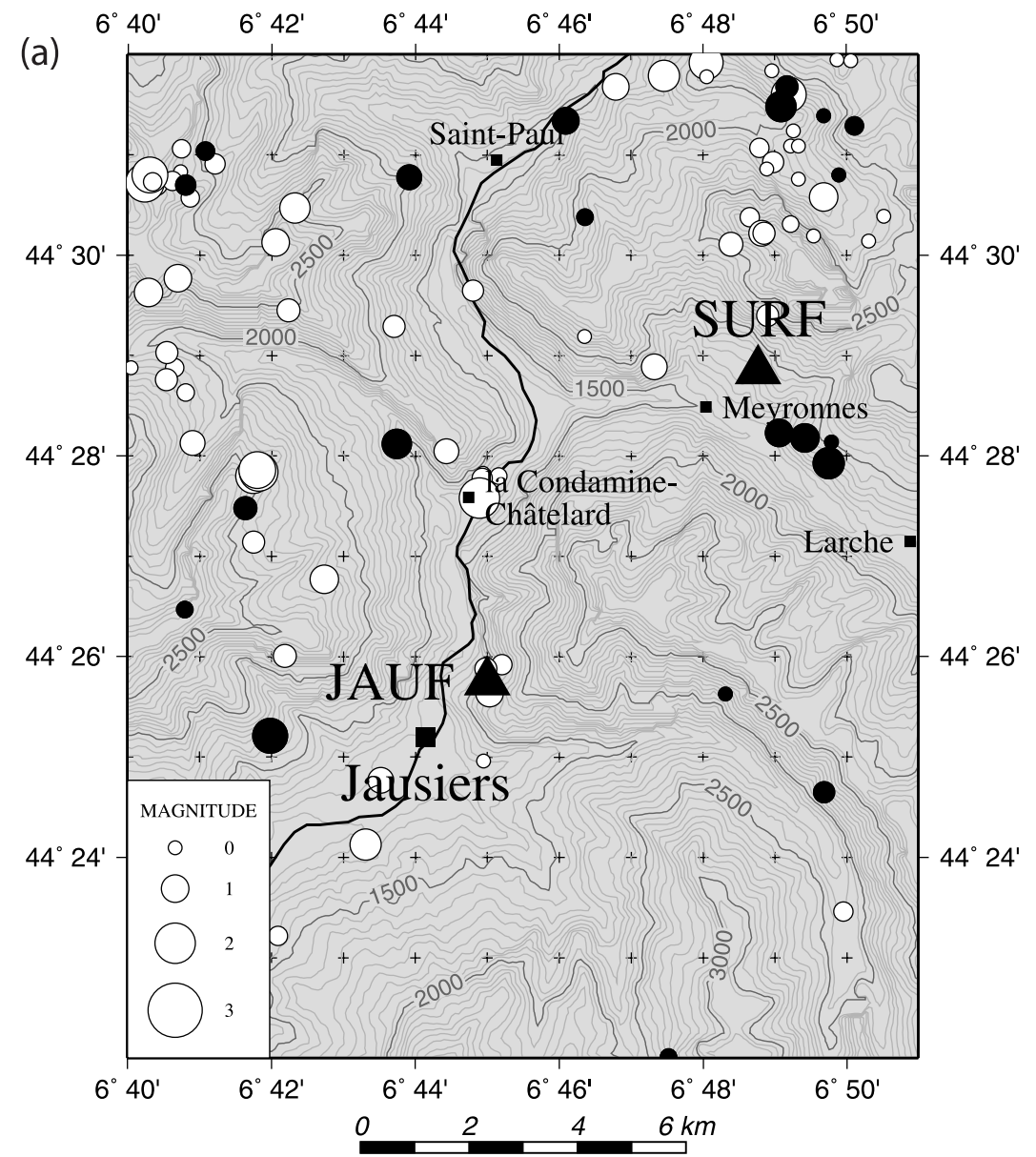

Figure 2. Double-difference locations for earthquakes in the study area. (a) Study period 1989-2002, with 2001-2002 events in black, for comparison with Figure 2b. (b) Study period 2003-2004. Triangles are permanent seismic stations JAUF and SURF. Cl. 1, 2, and 3 are three clusters discussed in the text. Topographic contours are at 50-m vertical intervals (SRTM data).

the boundary between France and Italy. Data gathered at that time by permanent seismic networks showed that the swarm had been active over several months altogether. For a few $M_{L}>3$ events, normal fault mechanisms were obtained with an east-west trending tension axis. Out of the many other swarms observed in Ubaye the 250-event 1989 swarm was more specifically studied using doublet analysis [Guyoton et al., 1990], but the scarcity of data then available allowed the relocation of seven events only.

\section{Data and Techniques}

[8] The active zone of the 2003-2004 earthquake swarm is centered on La Condamine-Châtelard (LCC) (Figure 2), a 200-inhabitant locality where about 200 earthquakes have been felt. (The smallest magnitude reported felt was 1.3). Since 1989, the seismic activity of this area has been monitored by Sismalp (Observatoire de Grenoble), a 44-station seismic network spread over the French Alps from the Lake of Geneva to Corsica, and adjacent seismic networks in Italy and France. Sismalp stations are equipped with one- or three-component $1-\mathrm{Hz}$ seismometers. Time synchronization is provided by radio or GPS. Each station is individually triggered using a short-term/long-term average algorithm.
Data are stored in random access memory before being retrieved through switched telephone lines. Two permanent Sismalp stations (Jausiers (JAUF) and St-Ours (SURF)) are located in the study area.

[9] For this study, earthquakes were first picked and located using the PICKEV2000 software (J. Fréchet and F. Thouvenot, 2000, http://sismalp.obs.ujf-grenoble.fr/ftpsismalp/msdos/), which enables an interactive control of picks. We then used HYPREF2005 (J. Fréchet, 2005, http:// sismalp.obs.ujf-grenoble.fr/ftp-sismalp/unix/), a modified version of the HYPO71 program [Lee and Lahr, 1975], which takes second arrivals and station altitudes into account. We eventually formed traveltime differences from $P$ and $S$ picks and used the HYPODD program [Waldhauser and Ellsworth, 2000; Waldhauser, 2001] to improve location precision.

[10] Out of the initial 252 events located over the 19892002 period, only 116 were relocated (Figure 2a); for the 2003-2004 earthquake swarm (Figure 2b), 1616 events were located and 1070 were relocated. There are three reasons for this low rate of relocated events: (1) Sismalp stations are triggered and detect earthquakes only when the signal-to-noise ratio is sufficiently high, which means that 




Figure 2. (continued)

small-magnitude events are recorded by the nearest stations only (on the other hand, arrivals are easier to identify on seismograms, and picks are more reliable), (2) in the HYPODD procedure we excluded stations at distances larger than $200 \mathrm{~km}$, and (3) we selected event pairs with a maximum separation distance of $10 \mathrm{~km}$ between hypocenters and with at least eight phase links, which excludes many events recorded by few stations.

[11] Over the 1989-2002 period the largest magnitude (2.0) is found for an event which occurred in 1996 just beneath LCC. The seismic activity was variable: There were no relocated events in 2000 compared to 29 in 1995 . In 2001-2002, if one scrutinizes the map of Figure 2a in the place where the earthquake swarm occurred (Figure 2b), only one event could be relocated, $2 \mathrm{~km} \mathrm{NW}$ of LCC (18 March 2001, $M_{L}=1.2$ ). During the same period every 2 days JAUF detected about one (usually nonlocatable) event with an $S-P$ smaller than $1 \mathrm{~s}$, which can be considered the background activity of the area close to LCC. The activity monitored at JAUF slightly increased in the last 2 weeks of December 2002 (one event per day), a few days before the commencement of the earthquake swarm in January 2003.

[12] In Figure 2b (2003-2004 earthquake swarm) the active zone stretches across the Ubaye valley just south of LCC along a 9-km-long alignment (cluster 1) which trends $143^{\circ} \mathrm{E}$ in its northwestern part, then veers to $152^{\circ} \mathrm{E}$ to the
SE. Besides cluster 1, two other clusters are of particular interest. Cluster 2 to the NW, $3.5 \mathrm{~km}$ from the NW tip of cluster 1, seems elongated along a WSW-ENE direction, which might evidence a 1-km-long fault conjugate to the main fault zone of cluster 1. Cluster 3 is farther to the NE,

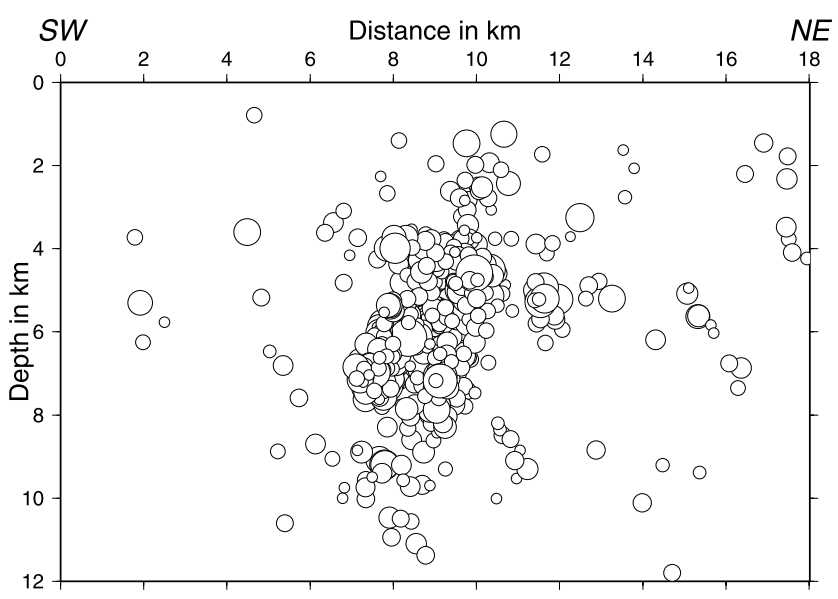

Figure 3. SW-NE section across the 2003-2004 earthquake swarm (double-difference locations). Midpoint on the distance axis $\left(\mathrm{km} \mathrm{9)}\right.$ is $44^{\circ} 26.5^{\prime} \mathrm{N}, 6^{\circ} 45^{\prime} \mathrm{E}$. Depth refers to sea level. 


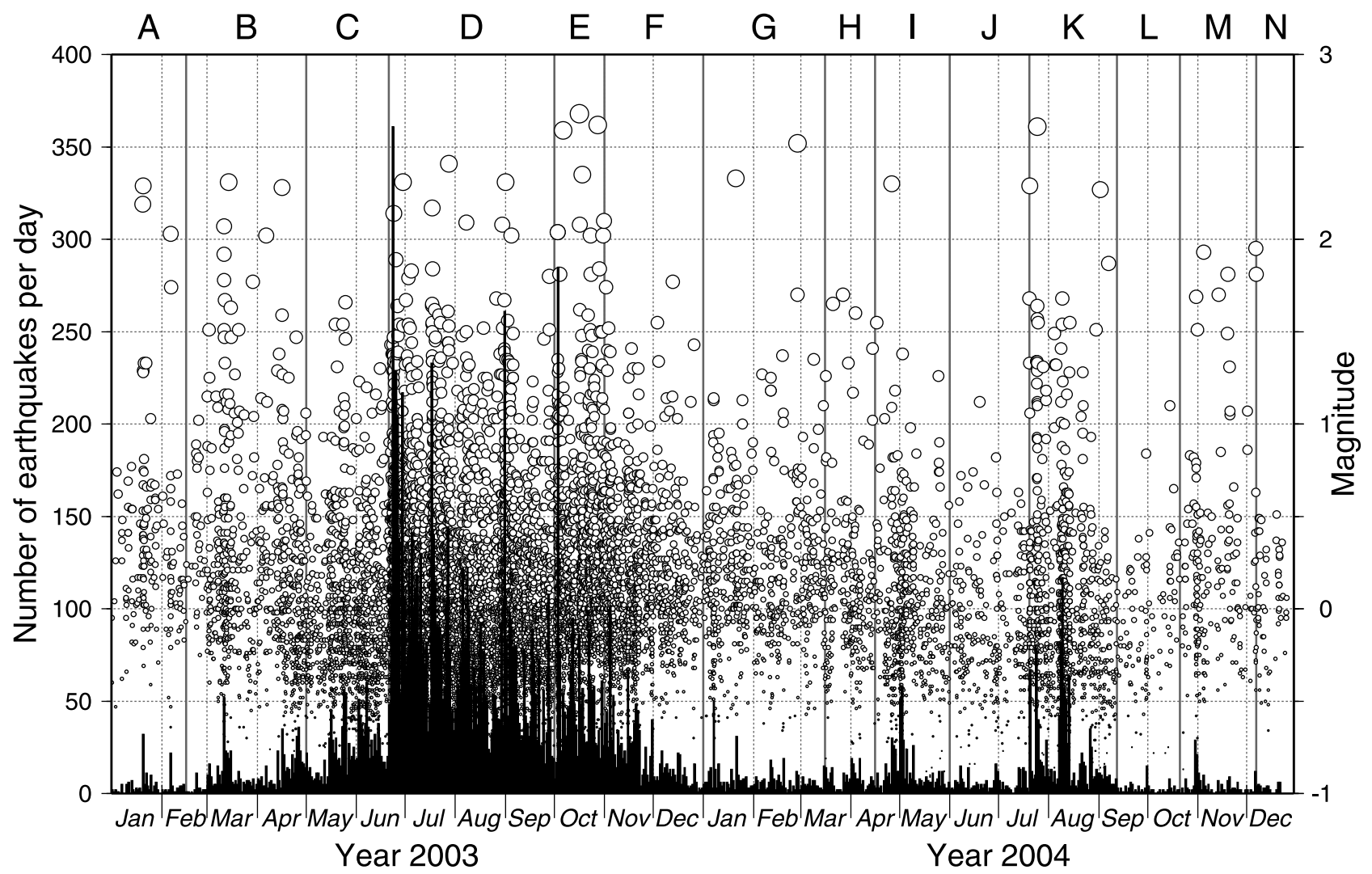

Figure 4. Complete time series for the $\sim 16,000$ events of the 2003-2004 swarm. Labels on top are phases of Table 1 .

$1.5 \mathrm{~km}$ from LCC. A SW-NE cross section (Figure 3) shows a 2-km-wide seismogenic zone whose actual thickness is probably increased by the change in trend of cluster 1 . Most events occur in the crystalline basement, in the 3 - to $8-\mathrm{km}$ depth range (in reference to sea level) and in the 5- to $10-\mathrm{km}$ depth range below the surface, given the mean altitude of $2000 \mathrm{~m}$ of the epicentral area. The fault zone dips $\sim 80^{\circ}$ to the SW.

[13] Station JAUF, situated above the swarm, recorded many small-magnitude shocks whose epicenters cannot be located. For more than 14,500 of them, $P$ and $S$ wave arrivals can be read on seismograms, with $S-P$ intervals providing hypocentral distances and origin times. To include magnitude estimates in this time series, we proceed as follows: For larger-magnitude events (data set 1), $M_{L}$ magnitudes are classically computed by taking into account the peak ground motion recorded at the different stations of the monitoring network. As the JAUF epicentral distances are close to zero and the minute peak ground motions measured for the small-magnitude shocks (data set 2) cannot be used the same way as in the Richter procedure, we use data set 1 to calibrate station JAUF for data set 2 as follows: (1) Each event in data set 1 provides a triplet (hypocentral distance to JAUF, log (peak ground motion at JAUF), and $\left.M_{L}\right),(2)$ in the distance-log (amplitude) plane, $M_{L}$ values are smoothed by a surface [Smith and Wessel, 1990], and (3) this surface is extrapolated and used for computing $M_{L}$ for data set 2 . This procedure ensures a full consistency for $M_{L}$, calculated for both data sets.
[14] Figure 4 shows the complete time series for the $\sim 16,000$ events. Magnitudes range from -1.3 to 2.7 . The number of events detected per day at station JAUF is superimposed on this data set. Both diagrams point to the variability of the activity during 2003-2004. Although no clear subswarms can be identified, as usually observed in other similar studies of earthquake swarms in intraplate regions, several phases can be tentatively recognized (Table 1). Bakun's [1984] relation between $M_{L}$ and the seismic moment $M_{0}$,

$$
\log _{10} M_{0}=1.2 M_{L}+10
$$

although derived for Californian earthquakes in the 1.53.5 $M_{L}$ range, can be used here to estimate the cumulated seismic moment $M_{0}=5.5310^{14} \mathrm{~N}$ m for the whole swarm. This corresponds to a magnitude 4 single event.

[15] Using the Fortran program FPFIT [Reasenberg and Oppenheimer, 1985], we computed 38 focal mechanisms (Figures 5 and 6) for events which occurred in 2003 and whose magnitudes were sufficient to allow the permanent seismic networks to record reliable first-motion polarities. More than half of the mechanisms imply strike slip, with one of the nodal planes striking NW-SE, and right lateral slip if that plane is chosen as the fault plane. This is especially the case for events in October 2003 (phase E) but also to a lesser extent during the swarm initiation (phases A and B) and at the end of the climactic phase D. About one third of the solutions in Figure 6 correspond to normal faulting mechanisms with tension axes trending 
Table 1. Chronology of the Swarm Activity ${ }^{a}$

\begin{tabular}{|c|c|c|c|c|}
\hline Phase & Period & Maximum $M_{L}$ & $\begin{array}{l}\text { Average Number } \\
\text { of Events per Day }\end{array}$ & Comments \\
\hline A & 1 Jan to 15 Feb 2003 & 2.3 & $<4$ & swarm initiation \\
\hline B & $16 \mathrm{Feb}$ to $30 \mathrm{Apr} 2003$ & 2.3 & 10 & slight activity increase \\
\hline $\mathrm{C}$ & 1 May to 20 June 2003 & 1.7 & 23 & $\begin{array}{l}\text { false impression of fading activity } \\
\text { (in terms of energy release) }\end{array}$ \\
\hline $\mathrm{D}$ & 21 June to 30 Sep 2003 & 2.4 & 80 & $\begin{array}{l}\text { climax of the phenomenon in terms } \\
\text { of events ( } 361 \text { events on } \\
23 \text { Jun 2003); clear activity } \\
\text { decrease at the end of } \\
\text { September }\end{array}$ \\
\hline $\mathrm{E}$ & $1-31$ Oct 2003 & 2.7 & 52 & $\begin{array}{l}\text { new burst of activity ( } 285 \text { events on } \\
3 \text { Oct } 2003 \text { ), soon followed by } \\
\text { three shocks of } M_{L}: 2.6,2.7 \text {, } \\
\text { and } 2.6\end{array}$ \\
\hline $\mathrm{F}$ & 1 Nov to 31 Dec 2003 & 1.8 & 20 & activity decrease \\
\hline G & 1 Jan to 15 Mar 2004 & 2.5 & 7 & $\begin{array}{l}\text { low activity but still two shocks } \\
\text { with } M_{L}>2\end{array}$ \\
\hline $\mathrm{H}$ & 16 Mar to 15 Apr 2004 & 1.7 & 7 & new activity decrease \\
\hline I & 16 Apr to 31 May 2004 & 2.3 & $11-12$ & slight activity increase \\
\hline $\mathrm{J}$ & 1 Jun to $19 \mathrm{Jul} 2004$ & 1.1 & 5 & quiescent period \\
\hline $\mathrm{K}$ & $20 \mathrm{Jul}$ to $11 \mathrm{Sep} 2004$ & 2.6 & 21 & $\begin{array}{l}\text { new burst of activity, soon followed } \\
\text { by an } M_{L}-2.6 \text { shock; the } \\
\text { activity culminates on } 9 \text { Aug } \\
2004 \text { (117 events) }\end{array}$ \\
\hline $\mathrm{L}$ & $12 \mathrm{Sep}$ to 20 Oct 2004 & 1.1 & $<3$ & new quiescent period \\
\hline $\mathrm{M}$ & 21 Oct to 6 Dec 2004 & 2.0 & $<4$ & ultimate energy release \\
\hline $\mathrm{N}$ & 7-31 Dec 2004 & 0.5 & $<2$ & $\begin{array}{l}\text { at the very end of December, no } \\
\text { event detected for } 5 \text { consecutive } \\
\text { days, the first instance since } \\
\text { the inception of the phenomenon }\end{array}$ \\
\hline
\end{tabular}

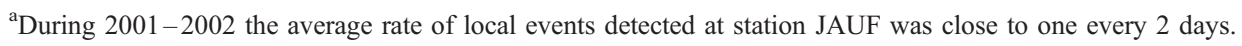

SW-NE to E-W. They occurred predominantly in June and July 2003 at the beginning of phase D. For only a few events the data require a reverse component, and in all such cases the dominant sense of movement is strike slip.

\section{Migration of Seismic Activity}

[16] The $\mathrm{N} 145^{\circ} \mathrm{E}$ direction corresponds to the mean trend of cluster 1 (Figure 2b). Along that direction we can follow the migration of the activity with time (Figure 7). The swarm initiated close to $\mathrm{km} 8$ of the distance axis (phase A). During phase B the activity jumped $1 \mathrm{~km}$ to the NW (km 7). The falsely quiescent phase $\mathrm{C}$ then began to activate a $4-\mathrm{km}$ segment of the alignment between $\mathrm{km} 6$ and 10. This zone was particularly active during the climactic phase D. During phase E, when a new burst of activity was soon followed by three shocks of magnitude 2.6, 2.7, and 2.6, the active zone further increased to reach a total length of $7 \mathrm{~km}$ (from $\mathrm{km} 5$ to 12). During phase F and the first half of phase $G$ (relative quiescence) the activity began to migrate to the SE; this is especially clear in December 2003 and January 2004 when most events clustered between $\mathrm{km} 10$ and 12. By midFebruary (second half of phase $\mathrm{G}$ ) the activity reappeared at $\mathrm{km} 7$ (the active zone of phase B), then (phase H) reached cluster $2(\mathrm{~km} \mathrm{1.5)}$. The slight increase in seismicity during phase I reactivated the segment between $\mathrm{km} 6$ and 12, while events clustered around $\mathrm{km} 10$ during the quiescence of phase J. The new burst of activity during phase $\mathrm{K}$ ruptured a previously silent zone, between $\mathrm{km} 12$ and 13. During the following quiescent period (phase L) the few events that could be located again clustered around $\mathrm{km} 7$; a closer look at a map view shows that they do not belong to cluster 1 but correspond to the initiation of cluster $3,1.5 \mathrm{~km}$ to the NE of LCC. The final burst of activity (phase M) first propagated the rupture to the $\mathrm{SE}$ up to $\mathrm{km} 15$, then fully activated cluster 3 . If we do not take cluster 2 into consideration, the active zone of cluster 1 has a total length of $9 \mathrm{~km}$, between $\mathrm{km} 6$ and 15.

[17] Another way to approach the migration of the seismic activity is presented in Figure 8, where snapshots corresponding to the different phases are shown in a vertical plane striking $\mathrm{N} 145^{\circ} \mathrm{E}$. Although a direct evaluation of uncertainties is difficult for relative locations of seismic events, the concentration of foci during phase A (swarm initiation) into a $\sim 500$-m-radius sphere implies that we can rely on hypocentral uncertainties probably much smaller than that 500-m value. Phase E, when three events reached a maximum magnitude of 2.6, 2.7, and 2.6, is characterized by activity in the central part of the swarm, at around a $6-\mathrm{km}$ depth. This zone happens to be where events with magnitude larger than 2 were relocated (see Figure 8, bottom right). Its southeastern tip was activated mainly during phase $\mathrm{K}$.

[18] A final remark concerns cluster 2, which appears on the left of the diagrams in Figure $8(\mathrm{~km} 1$ on the distance axis) in the 3- to 9-km depth range. The fact that focal depths for cluster 1 during phase A were shown to be very consistent and reliable substantiates foci for cluster 2 being spread over this 6-km depth range. Although the activity of cluster 2 was at its maximum during phases $\mathrm{G}$ and $\mathrm{H}$, Figure 8 shows that a few events occurred in this cluster earlier in the swarm sequence (phases C and D) and also 

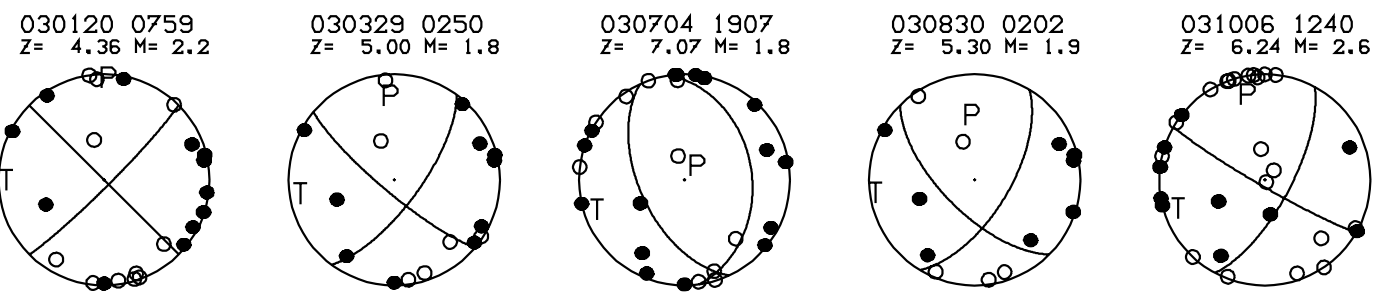

$\begin{array}{ll}031027 & 2057 \\ Z=6.78 & M=2.6\end{array}$
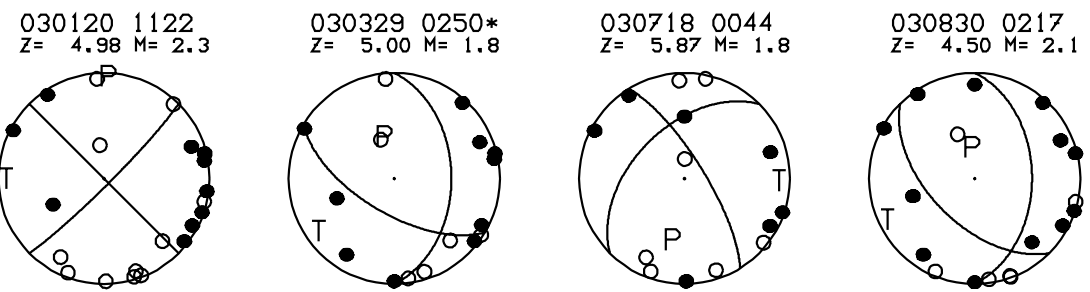

0310061918
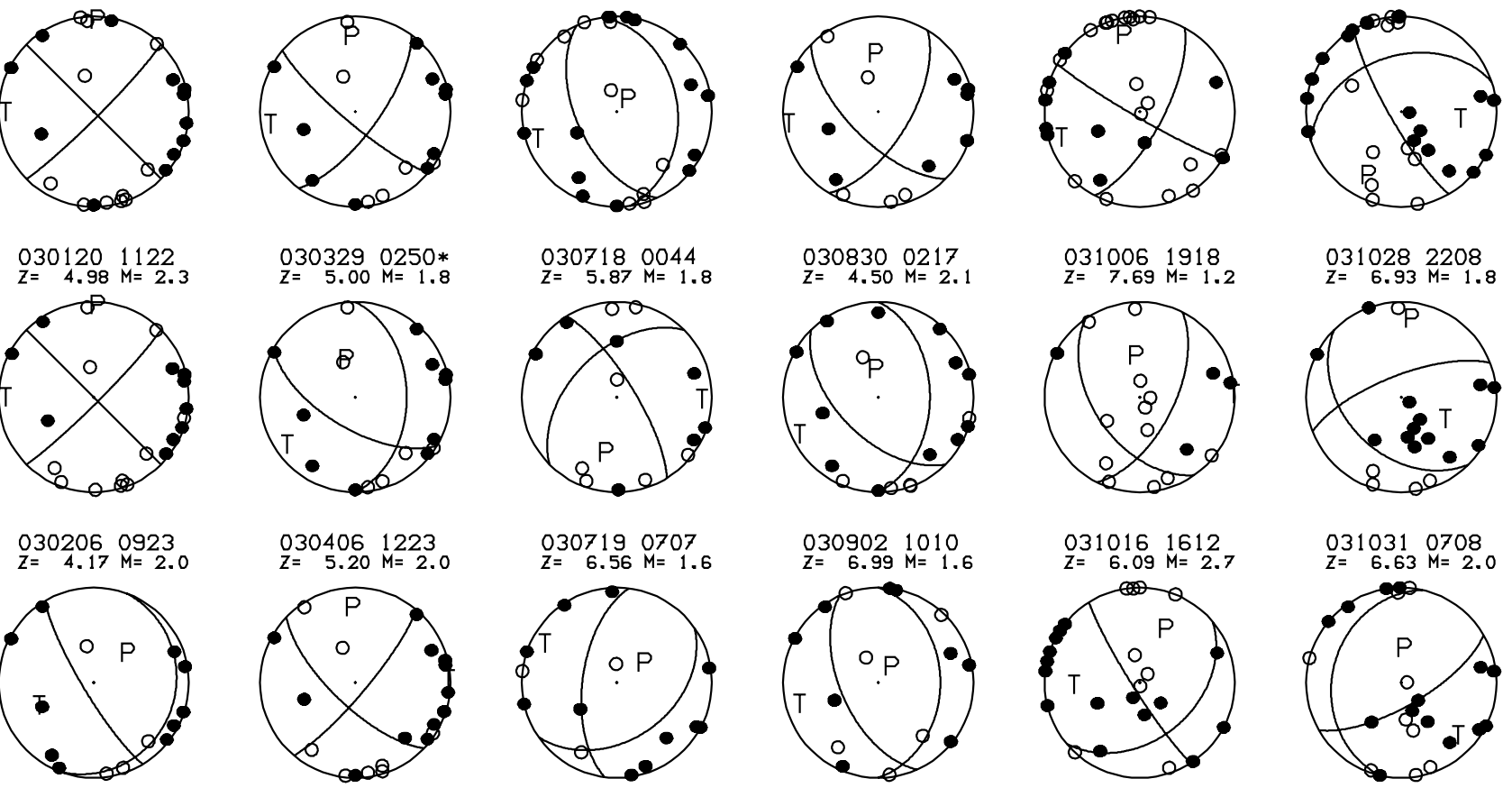

$\begin{array}{ll}031016 & 1612 \\ Z=6.09 & M=2.7\end{array}$

$\begin{array}{ll}031031 & 0708 \\ Z=6.63 & M=2.0\end{array}$
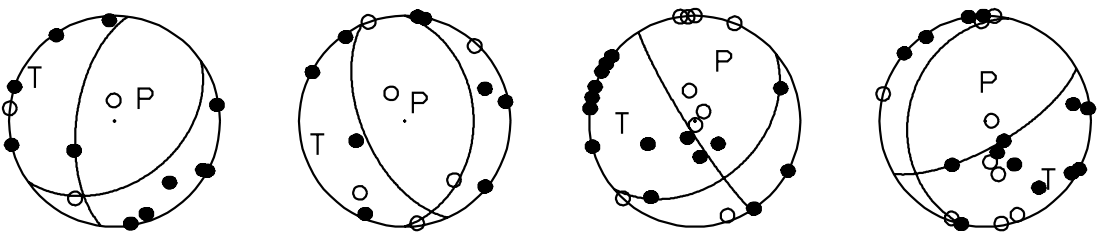

$\begin{array}{ll}030206 & 1727 \\ Z=4.50 & M=1.7\end{array}$
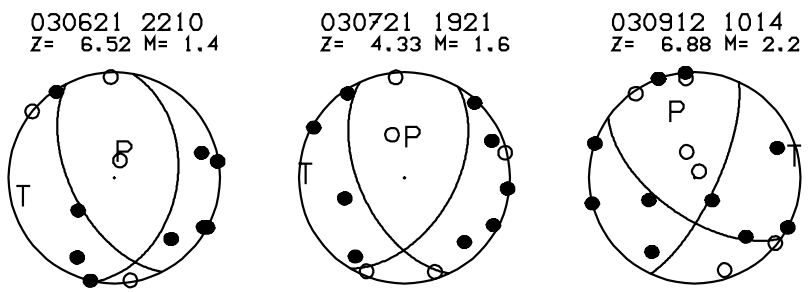

$\begin{array}{lll}031018 & 0538 \\ Z=4.88 & M=2.4\end{array}$

$\begin{array}{ll}031031 & 1454 \\ Z=6.71 & M=2.1\end{array}$
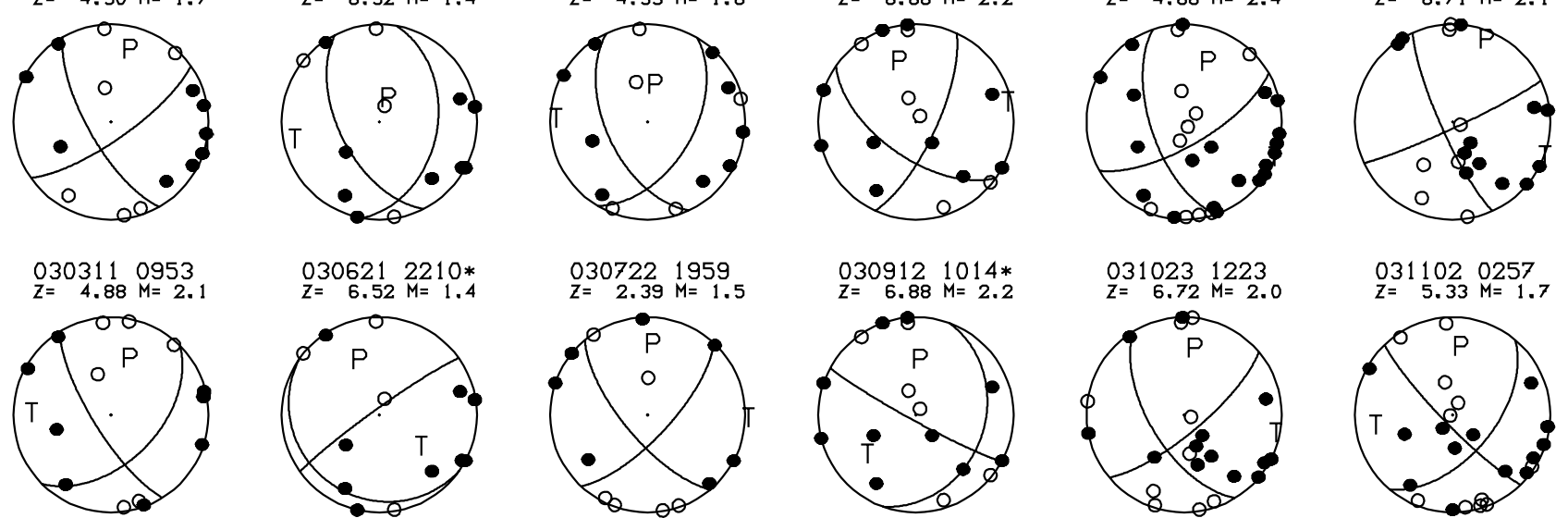

$030912 \quad 1014 *$

0310231223

$\begin{array}{ll}031102 & 0257 \\ Z=5.33 & M=1.7\end{array}$
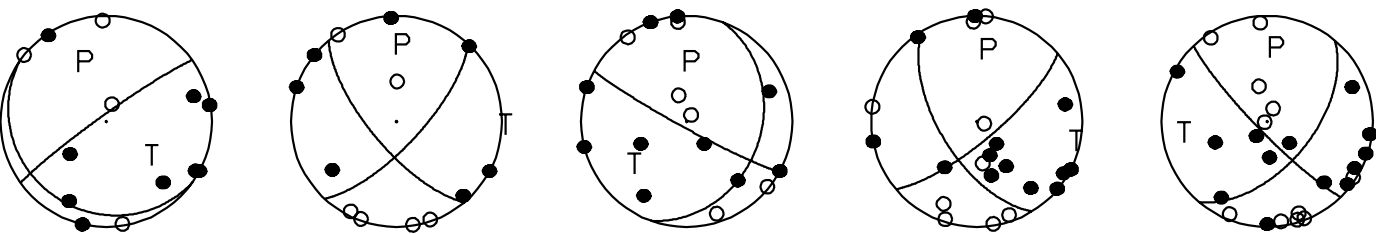

$\begin{array}{ll}030311 & 1001 \\ Z=4.91 & M=1.9\end{array}$
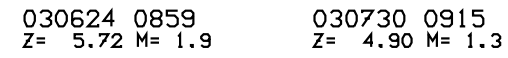

$\begin{array}{ll}030924 & 1341 \\ Z=4.60 & M=1.5\end{array}$

$\begin{array}{ll}031025 & 1836 \\ Z=5.46 \quad M=1.2\end{array}$

$\begin{array}{ll}031103 & 1534 \\ Z=6.26 & M=1.5\end{array}$
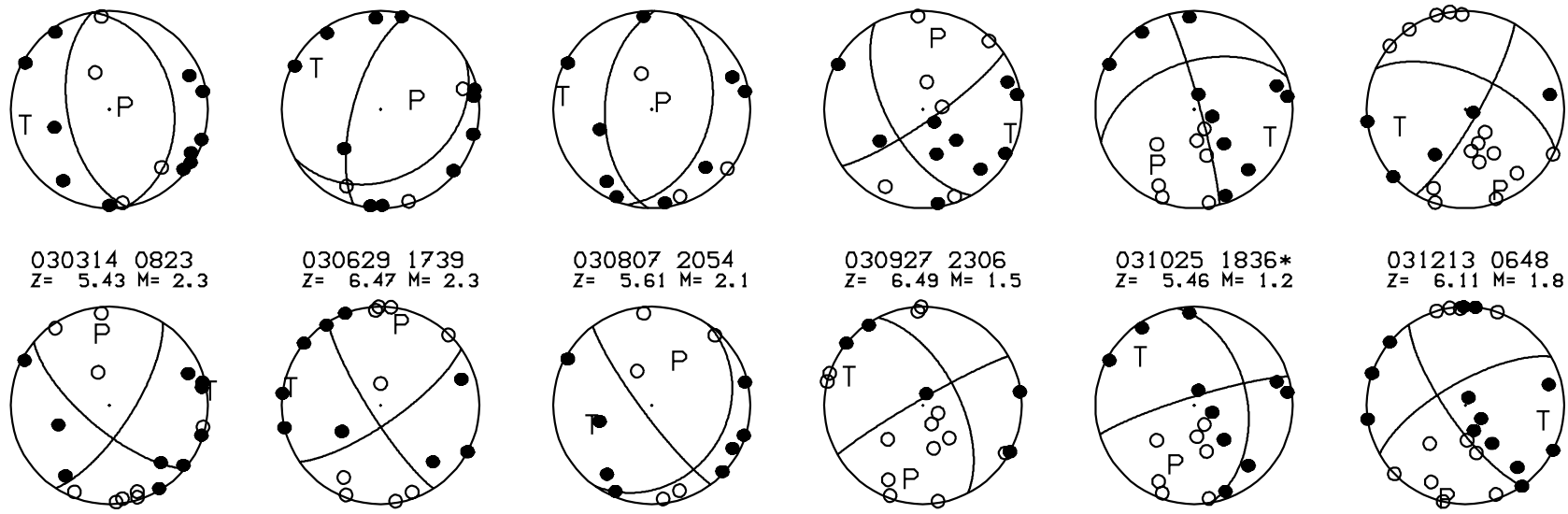

Figure 5. Focal mechanisms (lower hemisphere, equal area projection) for 38 events of the earthquake swarm. The heading over each diagram reads date, origin time, depth, and magnitude. In four instances the star indicates a double solution. 


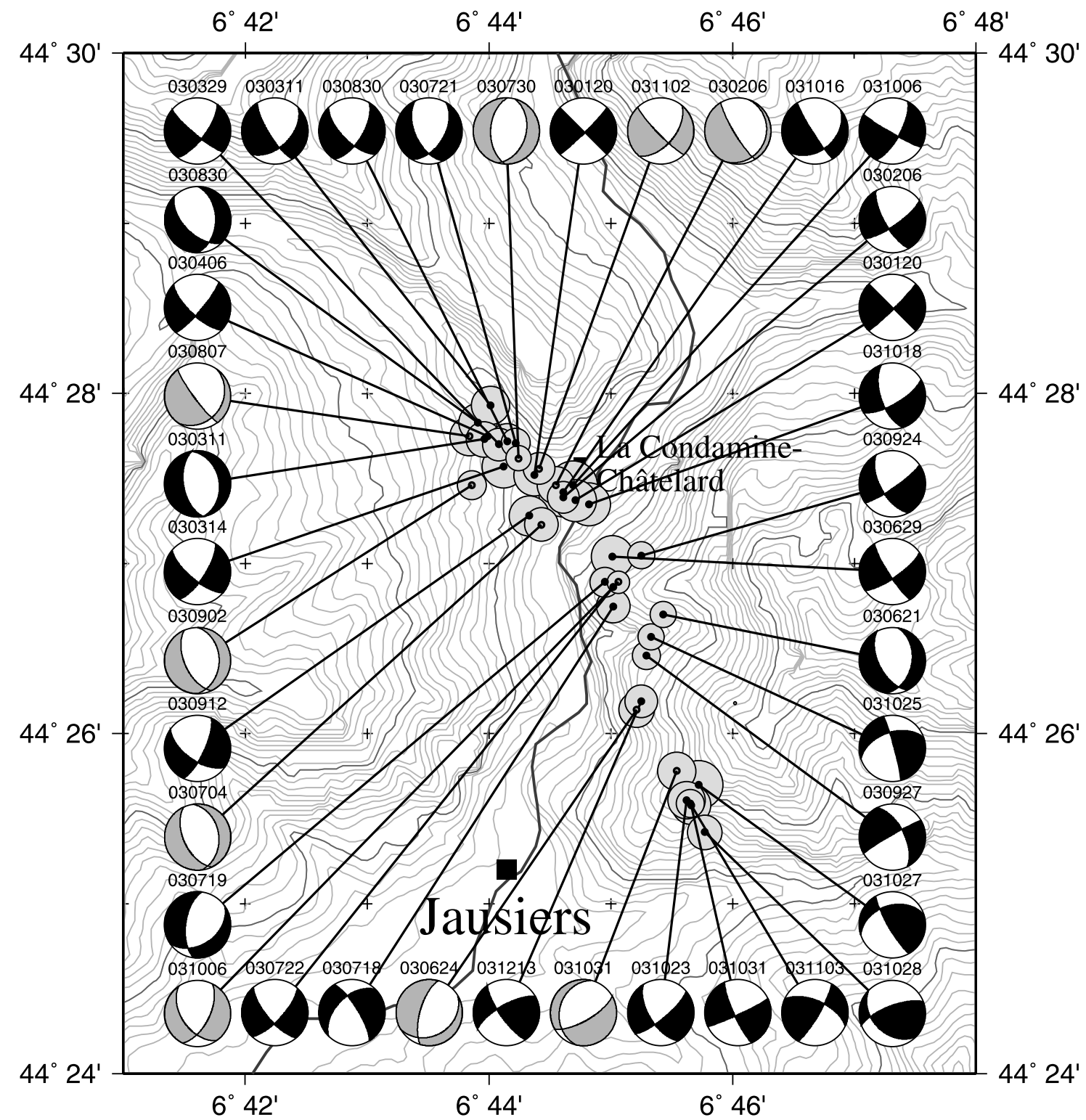

Figure 6. Focal mechanism map view for the 38 events of Figure 5. Compressional first motions are observed in filled quadrants. Less constrained mechanisms are lightly shaded. Label over each mechanism gives date of occurrence.

later (phases I, J, and L). However, one cannot observe for cluster 2 any upward or downward migration with time.

\section{Variation in $b$ Value}

[19] Earthquake populations are classically characterized by the Gutenberg-Richter law [Gutenberg and Richter, 1956]

$$
\log _{10} N=a-b M
$$

where $N$ is the number of earthquakes with magnitudes larger than or equal to $M$. We carried out a GutenbergRichter analysis of the 11,777 events located by Sismalp in the western Alps between 1989 and 2005. It provides us with a $b$ value of $0.95 \pm 0.03$, which is very close to the average value of 1.0 usually reported at a global scale. For earthquake swarms, it is frequent to observe $b$ values larger than 1.0, but $b$ values smaller than 1.0 are also sometimes found.

[20] Figure 9 shows the frequency-magnitude distribution for the $\sim 16,000$ events of the swarm sequence drawn up in section 3 (squares). The deviation from the GutenbergRichter law for negative magnitudes obviously results from our catalog being incomplete for small-magnitude earthquakes $\left(M_{\text {cut }} \sim 0\right)$. The $b$ value of $1.20 \pm 0.03$, a figure larger than that found for the western Alps as a whole $(0.95 \pm$ 0.03 ), was estimated by a maximum likelihood analysis. We used Utsu's [1966] discrete approach to compute

$$
b=\frac{-1}{\delta M} \log _{10}\left(1-\frac{\delta M}{\bar{M}-M_{\mathrm{cut}}}\right)
$$




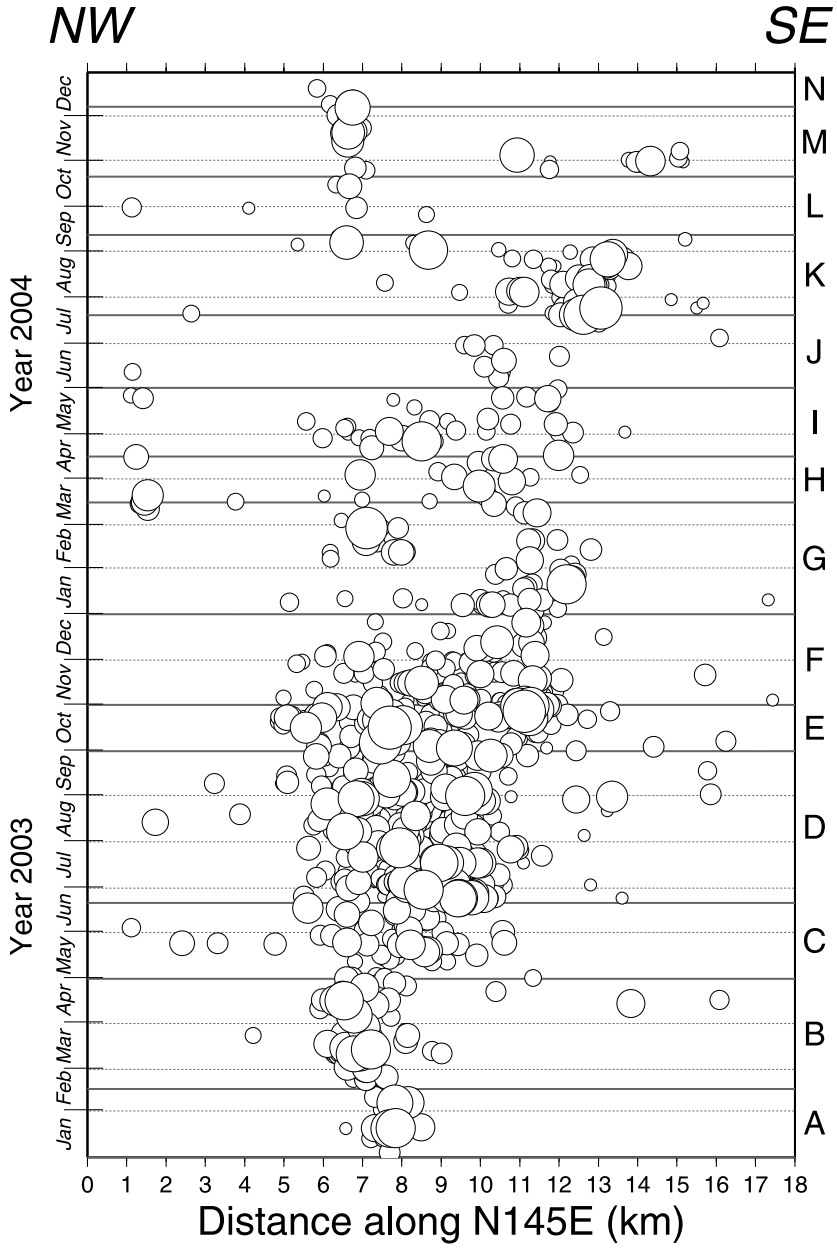

Figure 7. Migration of the activity during 2003-2004. The distance axis trends $\mathrm{N} 145^{\circ} \mathrm{E}$, with a midpoint $(\mathrm{km} \mathrm{9)}$ centered on $44^{\circ} 26.5^{\prime} \mathrm{N}, 6^{\circ} 45^{\prime} \mathrm{E}$. Labels on the right are phases of Table 1.

where $\delta M$ is the magnitude bin width (here $\delta M$ is 0.1 ) and $\bar{M}$ is the mean magnitude of the $N^{*}$ events above the $M_{\text {cut }}$ threshold. The $95 \%$ confidence level $\Delta b$ is

$$
\Delta b=1.96 \frac{b}{\sqrt{N^{*}}}
$$

[Aki, 1965].

[21] In Figure 9 the frequency-magnitude distribution is also shown for two extreme periods: 1 January to 25 April 2003 (circles, $b=1.03 \pm 0.09$ ) and 6-22 September 2003 (triangles, $b=1.53 \pm 0.19$ ). These two periods have different lengths (115 and 17 days, respectively), but both correspond to populations of 801 events, with 488 and 245 events above $M_{\text {cut }}$, respectively.

[22] The value of $b$ varies significantly with time. In Figure 10 we used a moving window of 801 events which left out 100 events and included 100 new events each time it was moved. This allowed us to compute $b$ at 154 different dates, each date being taken as that of the 401st event in the window. An 801-event window is a good trade-off; this figure ensures acceptable uncertainties on $b(0.09 \leq \Delta b \leq$
0.2 ), while increasing it would average possible rapid variations. Indeed, as a result of the variable activity, 801 events cover nearly 4 months at the beginning and at the end of the swarm, while the same number of earthquakes occurred within 3 days when the activity reached its climax (end of June 2003).

[23] The value of $b$ was close to 1.0 at the beginning of the swarm (phase A). It steadily increased during phases B and $\mathrm{C}$ up to $\sim 1.5$ and suddenly decreased when the activity burst out at the end of phase C. During the most active phases (D and $\mathrm{E}), b$ was in the $1.1-1.25$ range, but it again reached values larger than 1.4 over two short periods in July and September 2003. The $b$ value then steadily increased during phase $\mathrm{F}$ up to 1.4 before returning to its average 1.2 level during phase $\mathrm{H}$. (Phases F, G, and $\mathrm{H}$ are three periods where we noted activity decreased). It reached a value of $\sim 1.4$ again during phase I (slight activity increase in May 2004) and resumed its preswarm value of $\sim 1.0$ in phase K (August 2004). A conclusion which can be drawn from Figure 10 is that low and high $b$ values alternated during phases $\mathrm{D}$ and $\mathrm{E}$, when the swarm activity reached its climax. This could perhaps suggest a subdivision of phases $\mathrm{D}$ and $\mathrm{E}$ which we have not anticipated.

\section{Discussion and Conclusions}

[24] No fault has ever been mapped at the surface where the $\mathrm{N} 145^{\circ} \mathrm{E}$ trending, 9-km-long, 3- to 8-km-deep rupture zone imaged by the 1070 relocated events (Figure 2b) was identified. However, several faults or presumed faults striking $\mathrm{N} 140^{\circ} \mathrm{E}$ can be found on the detailed 1:50,000 geological maps of the area [Kerckhove et al., 1974, 2005]. Senonian sediments (Flysch à Helminthoïdes) here consist of a series of fine-grained sandstones, lithographic limestones, foliated argillaceous limestones, and argillaceous schists. Sue [1998] also cross-checked faults identified on satellite images with field observations. He concluded that faults strike mainly $\mathrm{N} 160^{\circ} \mathrm{E}$ in the northern part of the area of Figure 1 and $N 130^{\circ} \mathrm{E}$ in its southeastern part. There can be at least four reasons for explaining why rupture corresponding to the earthquake swarm fault zone has never been recognized: (1) the foliated nature of the flysch, (2) the rough topography with altitude varying from 1200 to $3000 \mathrm{~m}$ over less than $3.5 \mathrm{~km}$, (3) moraines and screes hiding accessible outcrops, and (4) the depth at which the seismic activity takes place. At $3-8 \mathrm{~km}$ below sea level, foci are located in the pre-Triassic basement, and the overlying sedimentary cover is probably only slightly deformed. However, the basement fault zone is perhaps connected to several well-documented $\mathrm{N} 135^{\circ}-150^{\circ} \mathrm{E}$ striking faults in the northwestern tip of the Argentera crystalline massif, $15 \mathrm{~km}$ to the SE [Kerckhove et al., 1980].

[25] The seismic moment cumulated over the whole swarm corresponds to a single-event magnitude of 4 . This is not what can be derived from the 9-km-long, $\sim 15-\mathrm{km}^{2}$ rupture zone of cluster 1 , whose dimensions suggest a single event of much larger magnitude, at least 5.5 or even 6 . Similar disagreement was observed by Audin et al. [2002] in northeast France, where the 40-km-long Remiremont Fault Zone is activated by swarms with magnitudes which do not exceed 4.8. Conversely, during the 2000 swarm in Vogtland/NW Bohemia [Hainzl and Fischer, 2002] the 

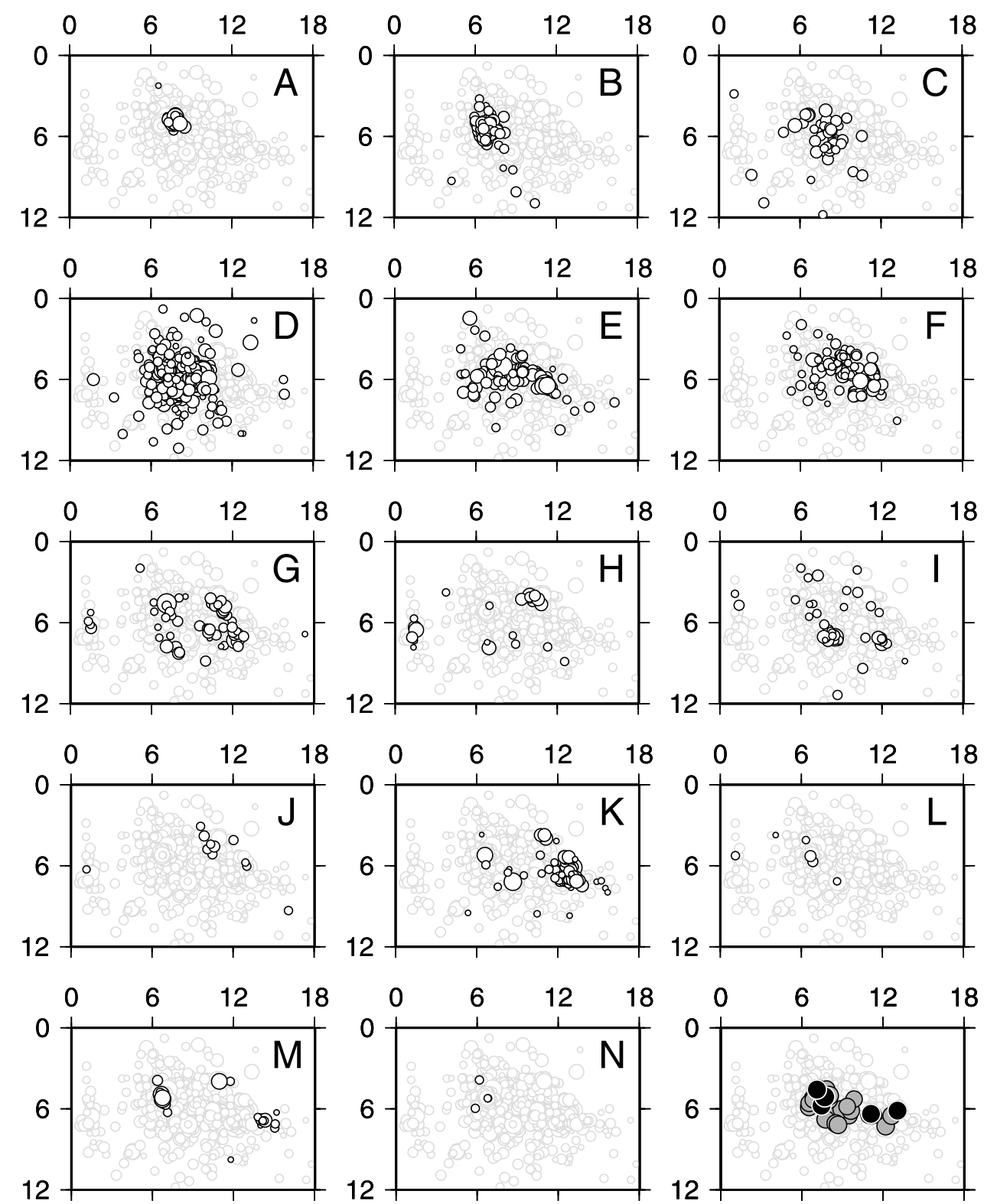

Figure 8. Snapshots of the swarm activity for the different phases of Table 1. The distance axis trends $\mathrm{N} 145^{\circ} \mathrm{E}$, with a midpoint $\left(\mathrm{km} \mathrm{9)}\right.$ centered on $44^{\circ} 26.5^{\prime} \mathrm{N}, 6^{\circ} 45^{\prime} \mathrm{E}$. Depth axis is from 0 to $12 \mathrm{~km}$. The lowermost diagram on the right shows the positions of events with magnitude larger than 2 (shaded circles) and larger than 2.5 (solid circles).

cumulated seismic moment yielded a 4.5 equivalent magnitude, a value consistent with the $3-\mathrm{km}$-long, $\sim 5-\mathrm{km}^{2}$ area of the main cluster. In Ubaye the difference between the cumulated magnitude of 4 and the potential magnitude of 5.5-6 derived from the fault zone size shows that aseismic slip is perhaps an unanticipated, important factor.

[26] Most of the 38 focal solutions computed in this study indicate either normal faulting with a SW-NE trending extension direction or NW-SE strike slip with right lateral displacement (Figure 6). The $\mathrm{N} 145^{\circ} \mathrm{E}$ direction of the $9-\mathrm{km}$ long active segment is consistent with the nodal planes of many focal mechanisms. Strike slip and normal faulting are most common in this part of the western Alps, as was recognized several years ago when a comprehensive study of the stress field was carried out [Sue, 1998; Sue et al.,
1999; Béthoux et al., 2007]. Strike slip is induced by the counterclockwise rotation of the Adriatic microplate relative to Eurasia about a pole sited farther east in northern Italy [Thouvenot and Fréchet, 2006]; extension radial to the belt, a process widely observed in the root zone of the western Alps [Sue et al., 1999], cannot be explained with a simple rigid plate model and probably also involves gravitational collapse and/or slab rollback or break off.

[27] Both extension and strike slip are processes usually closely related to earthquake swarms. In volcanic zones, characterized by extension regimes, swarms are common, and magma intrusions or related fluids are generally invoked to explain the migration of seismic activity [e.g., Śpičák et al., 1999]. We have shown in this study how the activity initiated in the central part of the rupture zone 


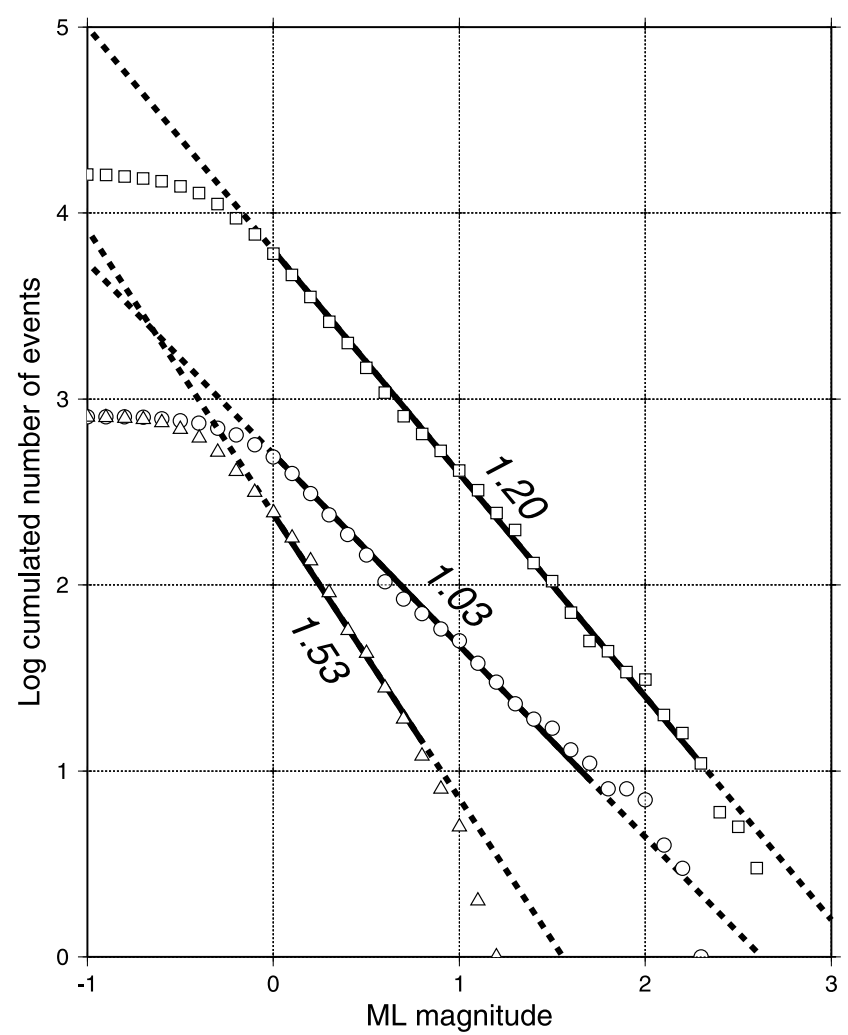

Figure 9. Cumulated frequency-magnitude distribution for the $\sim 16,000$ events, which yields a Gutenberg-Richter $b$ value of $1.20 \pm 0.03$ (squares). The frequency-magnitude distribution for two extreme periods is also shown: 1 January to 25 April 2003 (circles, $b=1.03 \pm 0.09$ ) and $6-$ 22 September 2003 (triangles, $b=1.53 \pm 0.19$ ). diffused to its periphery and eventually concentrated in its southeastern deeper part. The radius of the active zone clearly did not increase linearly with time, but whether its growth was governed by a diffusion law is not demonstrated yet. However, it cannot be disputed that a $4-\mathrm{km}$ radius was reached at the end of phase D, 9 months after the swarm initiated. If this growth were controlled by fluid circulation, the corresponding hydraulic diffusivity which links radius $r$ to time $t$ [e.g., Shapiro et al., 2002],

$$
D=\frac{r^{2}}{4 \pi t}
$$

would be close to $0.05 \mathrm{~m}^{2} \mathrm{~s}^{-1}$, of the order of values found in field experiments of induced seismicity where fluids are injected at a high rate [Shapiro et al., 2006]. However, we have no evidence for hydrothermal activity in Ubaye. The only data on fluid circulation are the Plan de Phasy hot spring, $25 \mathrm{~km}$ to the NNW (Figure 1), which is linked to $\mathrm{N} 160^{\circ} \mathrm{E}$ striking faults along the Durance river [Sue, 1998] and the Bagni di Vinádio hot spring, $30 \mathrm{~km}$ to the SE (Figure 1) in the midst of a $\mathrm{N} 150^{\circ} \mathrm{E}$ striking fault bundle which slashes the Argentera massif [Kerckhove et al., 1980]. To establish with finality the importance of fluid circulation in Ubaye, the characteristics of the diffusion law and the value of the hydraulic diffusivity still remain to be derived from the observed migration of seismic activity.

[28] The JAUF permanent station situated just above the earthquake swarm allowed us to monitor the entire phenomenon from its inception to its conclusion. The complete time series includes more than 16,000 events, with magnitude ranging from -1.3 to 2.7 and a cutoff magnitude close to 0 . We do not observe any subswarms but rather bursts of activity with a progressive start, separated by quiescent periods. By comparison, in Vogtland/NW Bohemia, nine subswarms were identified by Hainzl and Fischer [2002]

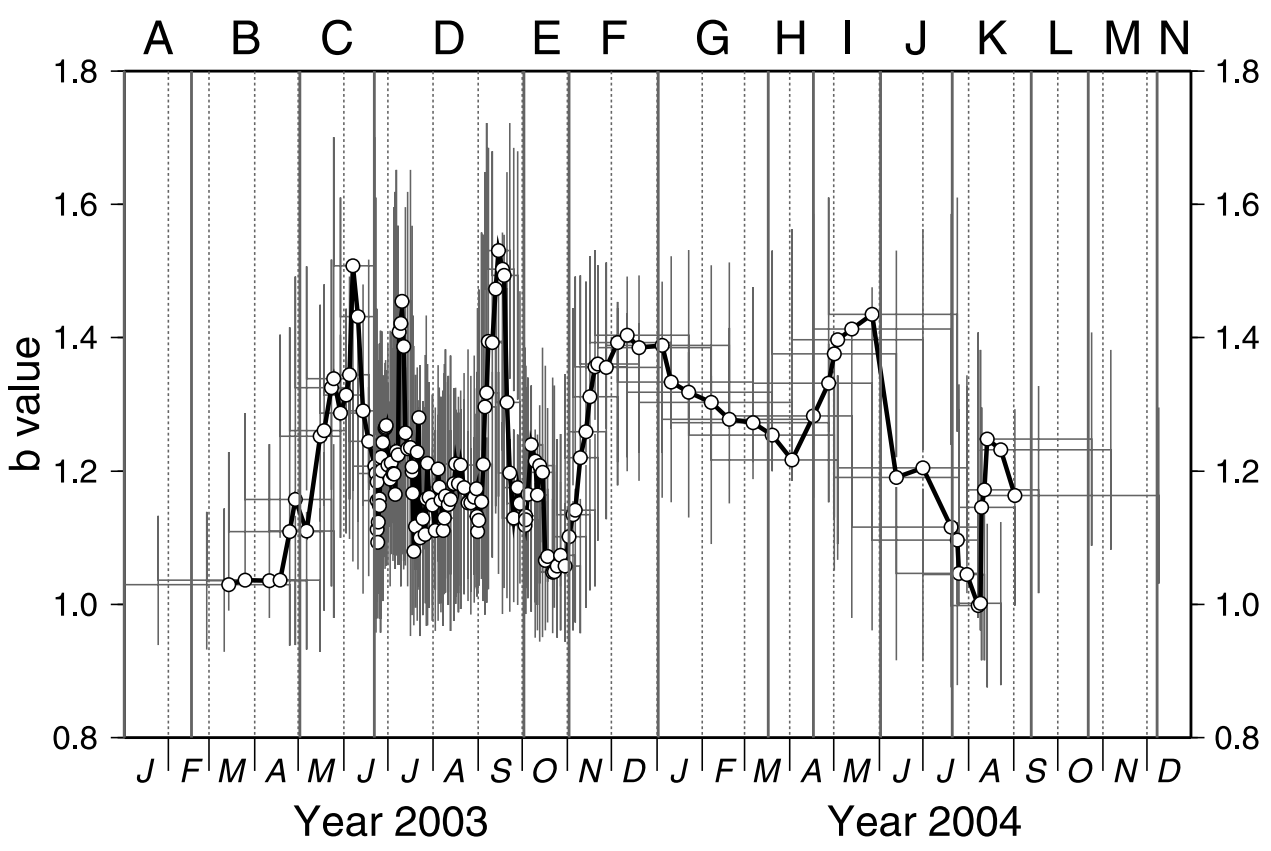

Figure 10. Variation in $b$ value during 2003-2004 (801-event moving window). Error bars and limits of time windows are shown for each $b$ value; labels on top are phases of Table 1. 
and Tittel and Wendt [2003] in the course of a 4-month swarm phenomenon in 2000. Of the many earthquake swarms described worldwide the phenomena observed in Vogtland are very similar to those in Ubaye. However, "simili non est idem" [Boswell, 1791] (i.e., similarity is not identity): in Vogtland, each subswarm (actually denoted "swarm phase" by the above authors) started suddenly, lasted 1-9 days, and was separated from the next phase by $2-26$ days.

[29] We found that the Gutenberg-Richter $b$ value significantly varied between 1.0 (at the start and the end of the swarm) and up to 1.5 when the swarm reached its climax. If we take again Vogtland/NW Bohemia for comparison, over the 4 months of the 2000 swarm, Hainzl and Fischer [2002] observed a $b$ value variation from 1.3 (when the swarm started) down to 0.8 in the midst of the activity. For the first half of the same data set and for slightly different time windows of the swarm phases, Tittel and Wendt [2003] found a similar but more limited variation (1.0 to 0.87$)$. This decrease of $b$ in the course of the swarm differs from the loose increase/decrease trend we observed in Ubaye, a result perhaps linked to the above mentioned difference for subswarms.

[30] Finally, as with all earthquake swarms the most puzzling problem remains that of the initiation and duration of the phenomenon. Ubaye is not usually visited by such prolific and protracted swarms. Curiously, there is a belief in this valley that earthquakes and flooding often coincide. Precipitation-induced seismicity has been reported in the central Alps [Roth et al., 1992; Deichmann et al., 2006]; the influence of seasonal groundwater recharge on seismicity has also been recognized elsewhere in the world [e.g., Saar and Manga, 2003]. Common sense sometimes contains valuable clues, but not in the present case because 2003 was a record dry year. Instead, it might be that fluid intrusion in the seismogenic zone initiated the process, as normally observed for other swarms in the area which last only a few days. However, in this particular case, perhaps because the state of the seismogenic zone was close to critical, the swarm could have evolved as a kind of selfsustained resonator where stress transfer and fluid circulation induced by each event allowed other events to occur. The phenomenon would have disappeared when the elastic energy stored in the fault mesh retrieved its subcritical level.

[31] Acknowledgments. Julien Fréchet designed the Sismalp network with us, and his contribution over nearly two decades is invaluable. The Conseil Général de l'Isère, the Délégation aux Risques Majeurs (French Ministry of the Environment), the Institut National des Sciences de l'Univers (CNRS), and the Conseil Régional Rhône-Alpes funded the Sismalp network. The Bureau Central Sismologique Français, the Observatoire de Grenoble, and several county councils (Isère, Alpes-de-HauteProvence, Haute-Savoie, Ain, and Savoie) support its running costs. Data from other seismic networks (RéNaSS, LDG, and IGG) were used when available, and we thank the relevant colleagues and technical staffs. This article benefited from discussions with G. Daniel, D. Marsan, and F. Renard and from helpful comments by P. Molnar, F. Waldhauser, and another anonymous reviewer. Figures were drawn using the GMT software [Wessel and Smith, 1998].

\section{References}

Aki, K. (1965), Maximum likelihood estimate of $\mathrm{b}$ in the formula $\log \mathrm{N}=$ a-bM and its confidence limits, Bull. Earthquake Res. Inst. Univ. Tokyo, 43, 237-239

Aoki, Y., P. Segall, T. Kato, P. Cervelli, and S. Shimada (1999), Imaging magma transport during the 1997 seismic swarm off the Izu Peninsula, Japan, Science, 286, 927-930.
Assumpção, M. (1981), The NW Scotland earthquake swarm of 1974 Geophys. J. R. Astron. Soc., 67, 577-586.

Audin, L., J.-P. Avouac, M. Flouzat, and J.-L. Plantet (2002), Fluid-driven seismicity in a stable tectonic context: The Remiremont fault zone, Vosges, France, Geophys. Res. Lett., 29(6), 1091, doi:10.1029/ 2001GL012988.

Bakun, W. H. (1984), Seismic moments, local magnitudes, and codaduration magnitudes for earthquakes in central California, Bull. Seismol. Soc. Am., 74, 439-458.

Béthoux, N., C. Sue, A. Paul, J. Virieux, J. Fréchet, F. Thouvenot, and M. Cattaneo (2007), Local tomography and focal mechanisms in the southwestern Alps: Comparison of methods and tectonic implications, Tectonophysics, 432, 1-19.

Boswell, J. (1791), The Life of Samuel Johnson, LL. D., vol. 1, Baldwin, London.

Bott, J. D. J., and I. G. Wong (1995), The 1986 Crested Butte earthquake swarm and its implications for seismogenesis in Colorado, Bull. Seismol. Soc. Am., 85, 1495-1500.

Chiu, J.-M., A. C. Johnston, A. G. Metzger, L. Haar, and J. Fletcher (1984), Analysis of analog and digital records of the 1982 Arkansas earthquake swarm, Bull. Seismol. Soc. Am., 74, 1721-1742.

Deichmann, N., M. Baer, J. Braunmiller, S. Husen, D. Fäh, D. Giardini, P. Kästli, U. Kradolfer, and S. Wiemer (2006), Earthquakes in Switzerland and surrounding regions during 2005, Eclogae Geol. Helv., 99, 443-452.

Fischer, T., and J. Horálek (2003), Space-time distribution of earthquake swarms in the principal focal zone of the NW Bohemia/Vogtland seismoactive region: Period 1985-2001, J. Geodyn., 35, 125-144.

Fréchet, J. (1978), Sismicité du Sud-Est de la France, et une nouvelle méthode de zonage sismique, thesis, Univ. Sci. Méd., Grenoble, France.

Fréchet, J., and N. Pavoni (1979), Etude de la sismicité de la zone briançonnaise entre Pelvoux et Argentera (Alpes occidentales) à l'aide d'un réseau de stations portables, Eclogae Geol. Helv., 72, 763-779.

Gutenberg, B., and C. F. Richter (1956), Earthquake magnitude, intensity, energy and acceleration, Bull. Seismol. Soc. Am., 46, 105-145.

Guyoton, F., J. Fréchet, and F. Thouvenot (1990), La crise sismique de Janvier 1989 en Haute-Ubaye (Alpes-de-Haute-Provence, France): Étude fine de la sismicité par le nouveau réseau Sismalp, C. R. Acad. Sci., Ser. II, 311, 985-991.

Hainzl, S., and T. Fischer (2002), Indications for a successively triggered rupture growth underlying the 2000 earthquake swarm in Vogtland/NW Bohemia, J. Geophys. Res., 107(B12), 2338, doi:10.1029/2002JB001865.

Kerckhove, C., M. Gidon, J.-L. Pairis, J. Plan, and D. Schneegans (1974), Feuille de Barcelonnette, Carte Géol. Fr. Map 895, scale 1:50,000, Bur. de Rech. Géol. et Min., Orléans, France.

Kerckhove, C., J.-C. Barfety, S. Bogdanoff, F. Carraro, M. Gidon, M. Jorda, M. Lemoine, R. Malaroda, and G. Montjuvent (1980), Feuille de Gap, Carte Géol. Fr. Map 35, scale 1:250,000, Bur. de Rech. Géol. et Min., Orléans, France.

Kerckhove, C., M. Gidon, and J.-L. Pairis (2005), Feuille de EmbrunGuillestre, Carte Géol. Fr. Map 871, scale 1:50,000, Bur. de Rech. Géol. et Min., Orléans, France.

Kisslinger, C. (1975), Processes during the Matsushiro swarm as revealed by levelling, gravity, and spring-flow observations, Geology, 3, 57-62.

Klinge, K., T. Plenefisch, and K. Stammler (2003), The earthquake swarm 2000 in the region Vogtland/NW-Bohemia-Earthquake recording at German stations and temporal distribution of events, J. Geodyn., 35, $83-96$.

Lee, W. H. K., and J. E. Lahr (1975), HYPO71: A computer program for determining hypocenter, magnitude, and first-motion pattern of local earthquakes, U. S. Geol. Surv. Open File Rep., 75-331, 110 pp.

Nicolas, M., N. Béthoux, and B. Madeddu (1998), Instrumental seismicity of the western Alps: A revised catalogue, Pure Appl. Geophys., 152, $707-731$

Noir, J., E. Jacques, S. Békri, P. M. Adler, P. Tapponnier, and G. C. P. King (1997), Fluid flow triggered migration of events in the 1989 Dobi earthquake sequence of central Afar, Geophys. Res. Lett., 24, 2335-2338.

Omori, F. (1894), On the aftershocks of earthquakes, J. Coll. Sci. Imp. Univ. Tokyo, 7, 111-200.

Reasenberg, P. A., and D. H. Oppenheimer (1985), FPFIT, FPPLOT and FPPAGE: FORTRAN computer programs for calculating and displaying earthquake fault-plane solutions, U. S. Geol. Surv. Open File Rep., 85739, 109 pp.

Roth, P., N. Pavoni, and N. Deichmann (1992), Seismotectonics of the eastern Swiss Alps and evidence for precipitation-induced variations of seismic activity, Tectonophysics, 207, 183-197.

Rothé, J.-P., and N. Dechevoy (1967), La séismicité de la France de 1951 à 1960, Ann. Inst. Phys. Globe Strasbourg, 8(3), 19-87.

Saar, M., and M. Manga (2003), Seismicity induced by seasonal groundwater recharge at Mt. Hood, Oregon, Earth Planet. Sci. Lett., 214, 505-618. 
Shapiro, S. A., E. Rothert, V. Rath, and J. Rindschwentner (2002), Characterization of fluid transport properties of reservoirs using induced microseismicity, Geophysics, 67, 112-220.

Shapiro, S. A., J. Kummerow, C. Dinske, G. Asch, E. Rothert, J. Erzinger, H.-J. Kümpel, and R. Kind (2006), Fluid induced seismicity guided by a continental fault: Injection experiment of 2004/2005 at the German Deep Drilling Site (KTB), Geophys. Res. Lett., 33, L01309, doi:10.1029/ 2005GL024659.

Smith, W. H. F., and P. Wessel (1990), Gridding with continuous curvature splines in tension, Geophysics, 55, 293-305.

Spičák, A. (2000), Earthquake swarms and accompanying phenomena in intraplate regions: A review, Stud. Geophys. Geod., 44, 89-106.

Špičák, A., J. Horálek, A. Boušková, C. Tomek, and J. Vanèk (1999), Magma intrusions and earthquake swarm occurrence in the western part of the Bohemian massif, Stud. Geophys. Geod., 43, 87-106.

Sue, C. (1998), Dynamique actuelle et récente des Alpes occidentales internes-Approches structurale et sismologique, thesis, Univ. Joseph Fourier Grenoble, France.

Sue, C., F. Thouvenot, J. Fréchet, and P. Tricart (1999), Widespread extension in the core of the western Alps revealed by earthquake analysis J. Geophys. Res., 104, 25,611-25,622.

Thouvenot, F., and J. Fréchet (2006), Seismicity along the northwestern edge of the Adria microplate, in The Adria Microplate: GPS Geodesy,
Tectonics, and Hazards, edited by N. Pinter et al., pp. 100-120, Springer, Dordrecht, Netherlands.

Tittel, B., and S. Wendt (2003), Magnitudes and time distribution of the swarm earthquakes August-November 2000 in NW Bohemia, J. Geodyn., 35, 97-105.

Utsu, T. (1966), A statistical significance test of the difference in b-value between two earthquake groups, J. Phys. Earth, 14, 37-40.

Waldhauser, F. (2001), HYPODD - A program to compute doubledifference hypocenter locations, U.S. Geol. Surv. Open File Rep., $01-113,25$ pp.

Waldhauser, F., and W. L. Ellsworth (2000), A double-difference earthquake location algorithm: Method and application to the northern Hayward Fault, California, Bull. Seismol. Soc. Am., 90, 1353-1368.

Wessel, P., and W. H. F. Smith (1998), New, improved version of Generic Mapping Tools released, Eos Trans. AGU, 79(47), 579.

N. Daix, R. Guiguet, L. Jenatton, and F. Thouvenot, LGIT, Observatoire de Grenoble, BP53, F-38041 Grenoble Cedex 9, France. (nicolas.daix@ obs.ujf-grenoble.fr; robert.guiguet@obs.ujf-grenoble.fr; liliane.jenatton@ obs.ujf-grenoble.fr; francois.thouvenot@obs.ujf-grenoble.fr) 